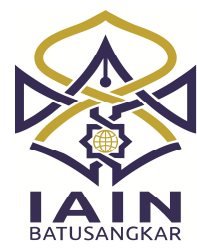

JURNAL TA'DIB, Vol 20 (2), 2017, (Juli-Desember)

(Cetak ISSN 1410-8208 Online ISSN 2580-2771)

Tersedia online di http://ecampus.iainbatusangkar.ac.id/ojs/index.php/takdib/index

\title{
Enhancing Students' Learning Outcome in Sport Class Through Student Facilitator and Explaining (SFE) Teaching Model
}

Aprizal*)

Dinas Pendidikan dan Kebudayaan

Kabupaten Tanah Datar Guru Kelas

SDN 23 Koto Hilir Kecamatan Padang

Ganting

Email :aprizal.spd.can@gmail.com
Abstract: An ineffective teaching strategy might have some drawbacks such as students' passiveness and lack of opportunities to exercise that cause the students difficult to comprehend rythmic gymnastic movement in Sport class. To improve the condition, the researcher conducts a Classroom Action Research (CAR) consisting of four stages; planning, acting, observing, and reflecting, by implementing a Student Facilitator and Explaining (SFE) teaching model which facilitates the students more chance to learn with peers. The subject of the research was the fourth grade of elementary school students of SDN 23 Koto Gadang Hilir Kecamatan Padang Ganting, Tanah Datar regency, academic year 2016/2017. The instruments of the research were both observation sheet and test. Cycle 1 result shows both the test result: $67 \%$ of psycomotoric and $71 \%$ cognitive aspects were successfully achieved, and the observasion result showing $83 \%$ of the teacher SFE activities and $77 \%$ students were active. Meanwhile, in Cycle 2, it is found that the students' psycomotor was increased to $88 \%$ and their cognition 93\%. The teacher's SFE activities were improved to $94 \%$ and $95 \%$ of the students were active. The results indicate that SFE teaching model could enhance the students' learning outcome in Sport class particularly on senam irama subject taught at the fourth grade of SDN 23 Koto Gadang Hilir Kecamatan Padang Ganting Tanah Datar regency.

Key words: Learning outcome, Sport Class, Student Facilitator and Explaining teaching model.

\section{PENDAHULUAN}

Pendidikan Jasmani adalah salah satu mata pelajaran yang diberikan sekolah baik sekolah negeri maupun swasta. Pendidikan jasmani merupakan bagian dari pendidikan nasional yang bertujuan sebagai sarana untuk mencapai tujuan pendidikan pada umumnya. Dalam proses pembelajaran Pendidikan Jasmani tidak dapat dipisahkan dari unsur permainan maupun bermain. Pendidikan Jasmani lebih diarahkan pada pemberian kesempatan belajar yang lebih luas dan suasana yang kondusif kepada siswa untuk memperoleh, dan mengembangkan pengetahuan, sikap, nilai serta keterampilan - keterampilan sosial yang bermanfaat bagi kehidupannya di masyarakat.

Pada dasarnya Pendidikan Jasmani merupakan aktivitas fisik melalui pembelajaran yang diarahkan dan mendorong kepada pendidik agar seluruh potensi peserta didik tumbuh dan berkembang untuk mencapai suatu tujuan secara utuh dan menyeluruh. Hal ini sesuai dengan yang tertuang dalam Undang undang Nomor 20 Tahun 2003 tentang Sistem Pendidikan Nasional mengungkapkan bahwa: "Pendidikan Jasmani merupakan media untuk mendorong pertumbuhan fisik, perkembangan psikis, keterampilan motorik, pengetahuan dan penalaran, penghayatan nilai - nilai (sikap - Mental emosional - sportivitas - spiritual - 
sosial), serta pembiasaan pola hidup sehat yang bermuara untuk merangsang pertumbuhan dan perkembangan kualitas fisik dan psikis yang seimbang".

Berdasarkan uraian tersebut Pendidikan Jasmani mempunyai peranan yang sangat penting dan berbeda yang menjadi ciri khas dibandingkan bidang studi lainnya, karena Pendidikan Jasmani tidak hanya mementingkan pengembangan intelektual tetapi pengembangan diri baik dari segi keterampilan menjadi hal yang dikembangkan dalam proses pembelajaran Pendidikan Jasmani.Hal ini menjadi kelebihan Pendidikan Jasmani itu sendiri, jika mata pelajaran lain lebih mementingkan pengembangan intelektual, maka melalui Pendidikan Jasmani akan terbina aspek - aspek atau ranah - ranah pendidikan jasmani yang menjadi ciri khas pendidikan diantaranya aspek kognitif, afektif, psikomotor maupun aspek sosial.

Peranan Guru Pendidikan Jasmani dalam hal ini harus dapat mengarahkan siswa ke arah tujuan yang sesuai dengan tujuan kurikulum yang telah diterapkan. Salah satucarayang ditempuh guru untuk membiasakan siswa terlibat dalam kegiatan belajar yang kondusif sesuai dengan pemaparan di atas dengan menggunakan model - model pembelajaran maupun metode - metode pengajaran yang bisa merangsang siswa untuk lebih termotivasi dalam mengikuti kegiatan belajar juga bisa membawa hasil yang diharapkan oleh kurikulum. Guru yang kreatif dalam pembelajaran memberikan aura yang positif pada kondisi pembelajaran itu sendiri, agar tujuan pembelajaran yang disampaikan tercapai dan mudah dipahami oleh siswa. Guru harusbisa memahami dan menguasai berbagai strategi, metode, mediapembelajaran, pendekatan dan model - model pembelajaran yang menunjang untuk berlangsungnya kegiatan pembelajaran di sekolah.

Hal diatas sangat berbeda dengan apa yang terjadi di SDN 23 Koto Gadang Hilir Kecamatan Padang Ganting
Kabupaten Tanah Datar pembelajaran pendidikan jasmani merupakan mata pelajaran yang sangat digemari siswa tetapi masih ada materi pembelajaran yang kurang mampu diterima siswa secara baik dalam kegiatan pembelajaran. Salah satu penyebabnya karena guru masih mendominasi jalannya pembelajaran. Saat pembelajaran diberikan siswa cenderung mendapat tekanan dan hanya menerima dari guru. Dalam kegiatan pembelajaran guru jarang sekali menggunakan metode yang berpusat dari siswa yang mampu mengembangkan kognitif siswa. Salah satunya adalah pembelajaran pada materi senam irama. Selama ini guru hanya menyajikan dengan bantuan kaset sehingga siswa kurang terlibat dalam kegiatan pembelajaran.

Dalam pembelajaran pendidikan jasmani pada materi senam irama siswa hanya menunggu guru dalam belajar padahal minat siswa pada materi ini sangat tinggi. Dalam kegiatan pembelajaran guru kurang mengawasi siswa dalam pembelajaran keran hanya mengamati secara umum saja. Evaluasi dalam kegiatan pembelajaran kurang berjalan dengan baik oleh guru. Hal ini berdampak terhadap hasil belajar yang diperoleh siswa pada pembelajaran pendidikan jasmani pada materi senam irama masih terbilang rendah.

Untuk mengatasi hal tersebut guru sebagai peneliti mencoba menggunakan model pembelajaran Student Facilitator and Explaining agar siswa mudah memahami pelajaran dan mudah menyerap pelajaran. Penulis mengganggap siswa akan mudah jika di contohkan gerakan olaharaga sebelum mereka melakukannya.Model pembelajaran ini lebih menekankan kepada aktivitas peserta didikdalam mengembangkan potensi yang dimiliki untuk dipaparkan kepada pesertadidik lain dengan cara sendiri yang diharapkan mudah dipahami dankomunikatif terhadap peserta didik lainnya.Suasana yang kompetitif perlu dihidupkan. Setiap kelompok harus 
mempunyai keinginan untuk menjadi yang terbaik. Oleh karena iti peran peserta didik sebagai facilitator sangat berpengaruh pada keberhasilan kelompok dalam mempelajari materi ajar yang dipelajari, selain juga aktivitas anggota kelompoknya. Dengan menggunakan model pembelajaran Student Facilitator and Explaining ini siswa bisa mengembangkan kreativitas dan Potensinya dengan caranya sendiri - sendiri untuk membantu temannya.

\section{KAJIAN TEORI \\ Hasil Belajar}

Hasil belajar merupakan suatu usaha untuk merubah tingkah laku seseorang peserta didik. Hasil belajar akan terlihat pada perubahan sikap dan prilaku yang ditunjukan oleh siswa. Guru perlu mengetahui hasil belajar dan kemajuan yang telah diperoleh siswa sebelumnya. Hal - hal yang perlu diketahui adalah antara lain penguasaan pelajaran dan keterampilan belajar. Pengetahuan dalam hal - hal tersebut penting artinya bagi guru, karena dengan mengetahui hal tersebut guru dapat membantu atau mendiagnosis kesulitan belajar siswa, memperkirakan hasil dan kemajuan selanjutnya, meskipun hasil - hasil tersebut dapat saja berbeda dan bervariasi sesuai dengan motivasi, kematangan dan lingkungan sosial.

Oemar Hamalik (2008:30) mengatakan hasil belajar adalah terjadinya perubahan tingkah laku pada orang tersebut, misalnya dari tidak tahu menjadi tahu, dari tidak mengerti menjadi mengerti". Menurut Nana (2009:3) "Hasil belajar adalah Perubahan tingkah laku individu yang mencakup aspek kognitif, afektif dan psikomotorik". Sedangkan Kunandar (2007:251) mengemukakan bahwa;Hasil belajar adalah kemampuan siswa dalam memenuhi suatu tahapan pencapaian pengalaman belajar dalam satu kompetensi dasar. Hasil belajar berfungsi sebagai petunjuk sebagai perubahan tingkah perilaku yang akan dicapai siswa sehubungan dengan kegiatan belajar yang dilakukan, sesuai dengan kompetensi dasar dan materi standar yang dikaji. Hasil belajar bisa berbentuk pengetahuan, keterampilan maupun sikap.

Berdasarkan pendapat para ahli diatas dapat disimpulkan bahwa hasil belajar adalah tingkat keberhasilan siswa dalam mempelajari materi yang telah diajarkan disekolah yang dapat terlihat pada perubahan tingkah lakunya misalnya dari tidak tahu menjadi tahu. Hasil belajar ini tidak hanya terlihat pada peningkatan pengetahuan saja tetapi juga dapat terlihat pada keterampilan dan perubahan resiko.

Dalam tujuan pendidikan yang ingin dicapai dikategorikan dalam bidang yaitu: kognitif, afektif dan psikomotorik. Ketiga aspek tersebut tidak dapat dipisahkan karena sebagai tujuan yang hendak dicapai. Dengan kata lain tujuan pengajaran diharapkan dapat dikuasai oleh siswa dalam mencapai 3aspek tersebut. Horward kingsley dalam Nana (2009:22) membagi tiga macam hasil belajar yaitu (a) Keterampilan dan kebiasaan (2) Pengetahuan dan pengertian (3) Sikap dan cita - cita. Banyak pendapat para ahli yang mengelompokan jenis hasil belajar ini. Selain itu Gagne dalam Nana (2009:22) membagi lima kategori hasil belajar antara lain (1) Informasi Verbal (2) Keterampilan intelektual (3) Strategis kognitif (4) Sikap (5) Keterampilan motoris.

\section{Model Pembelajaran Student Facilitator and Explaining}

Model Pembelajaran Student Facilitator and Explaining adalah model pembelajaran dimana siswa/peserta didik belajar mempresentasikan ide/pendapat pada rekan peserta didik lainnya. Model pembelajaran ini efektif untuk melatih siswa berbicara untuk menyampaikan ide/gagasan atau pendapatnya sendiri.

Langkah pembelajaran model pembelajaran Student Facilitator and Explaining adalah sebagai berikut: 
a. Guru menyampaikan kompetensi yang ingin dicapai.

b. Guru menyajikan garis besar materi pembelajaran.

c. Guru Memberikan kesempatan kepada facilitator untuk menjelaskan kepadatemannya, missal melalui peta konsep. Hal ini bias dilakukan secarabergiliran.

d. Guru menyimpulkan idea tau pendapat dari fasilitator.

e. Guru menerangkan materi (Agus Suprijono, 2009: 129).

Model pembelajaran ini lebih menekankan kepada aktivitas peserta didik dalam mengembangkan potensi yang dimiliki untuk dipaparkan kepada peserta didik lain dengan bahasa sendiri yang diharapkan mudah dipahami dan komunikatif terhadap peserta didik lainnya. Suasana yang kompetitif perlu dihidupkan. Setiap kelompok harus mempunyai keinginan untuk menjadi yang terbaik. Oleh karena iti peran peserta didik sebagai facilitator sangat berpengaruh pada keberhasilan kelompok dalam mempelajari materi ajar yang dipelajari, selain juga aktivitas anggota kelompoknya. Seorang facilitator baiknya memiliki kriteria:

a. Memiliki kemampuan akademis di atas rata-rata kelas.

b. Memiliki kemampuan untuk menjalin kerjasama dengan sesama peserta didik.

c. Memiliki motivasi yang tinggi untuk meraih prestasi akademis yang baik.

d. Memiliki sikap toleransi dan tenggang rasa dengan sesama peserta didik.

e. Memiliki motivasi tinggi untuk menjadikan kelompoknya menjadi yangterbaik.

f. Memiliki sikap rendah hati, pemberani, dan bertanggung jawab.

g. Suka membantu sesamanya yang mengalami kesulitan. (Agus Suprijono,2009: 130)
Pelatihan facilitator sangat penting. wawasan dan pengalaman facilitator akan meningkat, sehingga membuat facilitator merasa nyaman melakukantugasnya. Karena teman kelompoknya masih menganggap facilitator sebagaitemannya, sehingga diperlukan peranan pendidik untuk bisa membantu facilitator untuk bertanggung jawab terhadap kelompoknya. Pendidik juga harus menanamkan rasa menghargai kepada peserta didik untuk lebih menghormati facilitator.

Keuntungan yang bisa diambil dari penerapan model pembelajaran Student Facilitator and Explaining adalah:

a. Antar peserta didik akan lebih mudah bekerja sama dan komunikasi.

b. Facilitator mendapat pengertian materi lebih dalam dan juga menaikkankepercayaan dirinya karena mampu membantu teman.

c. Facilitator akan lebih sabar daripada guru terhadap peserta didik yang lambandalam belajar.

d. Lebih efektif daripada pelajaran biasa karena peserta didik yang lemah akandibantu tepat pada kekurangannya, peserta didik yang lemah dapat terus terangmemberi tahu Facilitator mana yang belum jelas tanpa malu-malu.

\section{Pembelajaran Pendidikan Jasmani}

Pendidikan jasmani Olahraga dan

Kesehatan merupakan bagian integral dari pendidikan secara keseluruhan, bertujuan untuk mengembangkan aspek kebugaran jasmani, keterampilan gerak, ketrampilan berfikir kritis, keterampilan sosial, penalaran, stabilitas emosional, tindakan moral, aspek pola hidup sehat dan pengenalan lingkungan bersih melalui aktivitas jasmani, olahraga dan kesehatan terpilih yang direncanakan secara sistematis dalam rangka mencapai pendidikan nasional.

Seperti yang tertuang dalam Depdiknas (2006:131) mengatakan bahwa pendidikan jasmani olahraga dan 
kesehatan merupakan satu mata ajar yang diberikan di suatu jenjang sekolah tertentu yang merupakan salah satu bagian dari pendidikan keseluruhan yang mengutamakan aktivitas jasmani dan pembinaan hidup sehat untuk bertumbuh dan perkembangan jasmani, mental, sosial dan emosional yang serasi, selaras dan seimbang. Menurut Sukintaka (2001:2) "pendidikan jasmani olahraga dan kesehatan merupakan bagian integral dari pendidikan total yang mencoba mencapai tujuan mengembangkan kebugaran jasmani, mental, sosial, serta emosional bagi masyarakat dengan wahana aktivitas jasmani".

Menurut Suherman (2004: 23) "Pendidikan jasmani olahraga dan kesehatan adalah suatu proses pembelajaran melalui aktivitas jasmani yang didesain untuk meningkatkan kebugaran jasmani, mengembangkan keterampilan motorik, pengetahuan dan perilaku hidup sehat dan aktif, dan sikap sportif, kecerdasan emosi”. Lingkungan belajar diatur seksama untuk meningkatkan pertumbuhan dan perkembangan seluruh ranah, jasmani, psikomotor, kognitif, dan afektif setiap siswa. Selain itu juga di kemukakan Kosasih (1992: 4)" mengemukakan bahwa pendidikan jasmani olahraga dan kesehatan ialah pendidikan yang mengaktualisasikan potensi aktivitas manusia yang berupa sikap tindak dan karya untuk diberi bentuk, isi dan arah menuju kebulatan kepribadian sesuai dengan cita-cita kemanusiaan".

Menurut uraian di atas dapat diambil kesimpulan bahwa Pendidikan Jasmani merupakan media untuk mendorong perkembangan keterampilan motorik kemampuan fisik, pengetahuan, penalaran, penghayatan nilai (sikap, mental, emosional, spiritual, sosial) dan pembiasaan pola hidup sehat yang bermuara untuk merangsang pertumbuhan serta perkembangan yang seimbang dalam rangka sistem pendidikan nasional. Dalam proses pembelajaran Pendidikan Jasmani guru diharapkan mengajarkan berbagai keterampilan gerak dasar, teknik dan strategi permainan dan olahraga, internalisasi nilainilai (sportifitas, jujur, kerjasama, dan lain-lain) serta pembiasaan pola hidup sehat. Pelaksanaannya bukan melalui pengajaran konvensional di dalam kelas yang bersifat kajian teoritis, namun melibatkan unsur fisik mental, intelektual, emosi dan sosial.

\section{METODE PENELITIAN}

Penelitian ini merupakan penelitian tindakan kelas yang dilakukan oleh guru untuk memperbaiki pelajaranpendidikan jasmanipada materi senam iramadiKelas IVSDN 23 Koto Gadang Hilir Kecamatan Padang Ganting Kabupaten Tanah Datar. Kegiatan dilakukan dengan memberikan materi senam irama dengan menggunakan model pembelajaran Student Facilitator and Explaining. Hal yang dilakukan dalam melakukan Penelitian ini pertama rencana kegiatan pembelajaran pendidikan jasmani pada materi senam iramadengan model pembelajaran Student Facilitator and Explainingdengan membuat RPP, soal tes, dan lembaran observasi untuk pengamatan. Setelah semua disiapkan guru mengajarpendidikan jasmani pada materi senam irama dengan model pembelajaran Student Facilitator and Explainingdan melakukan penilaian sehingga diperoleh hasil penelitian pada akhir kegiatan. Subjek dalam penelitian ini adalah siswa kelas IV SDN 23 Koto Gadang Hilir Kecamatan Padang Ganting Kabupaten Tanah Datar.Indikator keberhasilan pada penelitian ini ditetapkan pada awal pelaksanaan kegiatan yaitu $85 \%$ atau $>85 \%$ siswa tuntas dan siswa aktif maka dikatakan penelitian ini berhasil. Alur yang digunakan pada penelitian kelas ini dengan 4 tahapan, perencanaan, pelaksanaan, observasi dan refleksi.

Dalam penelitian ini data diperoleh dari hasil tes tulis dan lebaran observasi guru dan keaktifan siswa dalam belajar dan mengajar dengan model pembelajaran Student Facilitator and Explaining. 
Setelah data diperoleh secara keseluruhan data di olah menggunakan rumus yaitu $\frac{F}{N} \mathrm{x}$ $100 \%$.

\section{HASIL DAN PEMBAHASAN Hasil Belajar Siswa}

Setelah dilakukan kegiatan penelitian pada siklus I pertemuan I dan II siswa diberikan tes hasil belajar dari materi pertemuan I dan II siklus I. Hasil belajar pendidikan jasmani pada materi senam irama dengan model pembelajaran Student Facilitator and Explainingsiklus I pertemuan I dan II dari ranah psikomotor dan kognitif sebagai berikut:

Tabel 1: Hasil Belajar Psikomotor Siklus I

\begin{tabular}{|c|c|c|c|}
\hline \multicolumn{2}{|c|}{ Siklus I Pertemuan I } & \multicolumn{2}{c|}{ Siklus I Pertemuan II } \\
\hline $\begin{array}{c}\text { Siswa } \\
\text { Tuntas }\end{array}$ & $\begin{array}{c}\text { Siswa belum } \\
\text { tuntas }\end{array}$ & Siswa tuntas & $\begin{array}{c}\text { Siswa Belum } \\
\text { Tuntas }\end{array}$ \\
\hline $62 \%$ & $38 \%$ & $71 \%$ & $29 \%$ \\
\hline
\end{tabular}

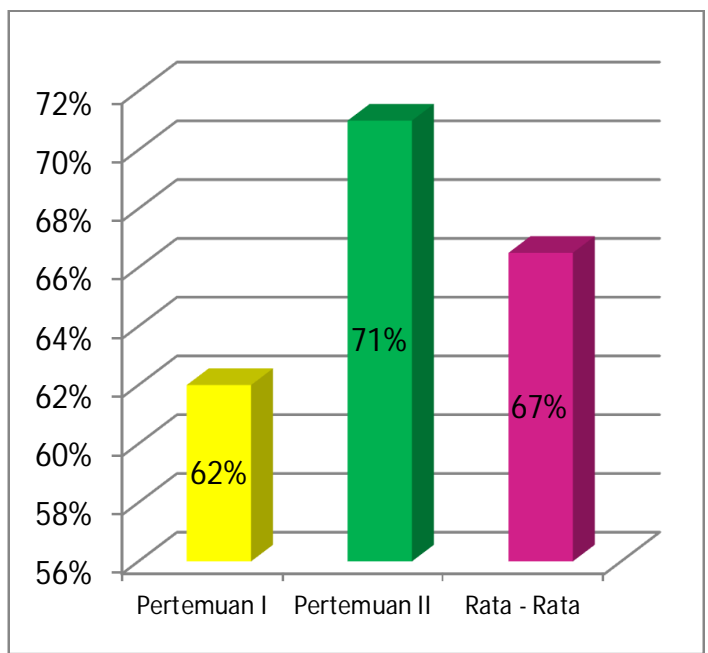

Tabel 2: Hasil Belajar Kognitif Siklus I

\begin{tabular}{|c|c|c|c|}
\hline \multicolumn{2}{|c|}{ Siklus I Pertemuan I } & \multicolumn{2}{c|}{ Siklus I Pertemuan II } \\
\hline $\begin{array}{c}\text { Siswa } \\
\text { Tuntas }\end{array}$ & $\begin{array}{c}\text { Siswa belum } \\
\text { tuntas }\end{array}$ & Siswa tuntas & $\begin{array}{c}\text { Siswa Belum } \\
\text { Tuntas }\end{array}$ \\
\hline $66 \%$ & $34 \%$ & $76 \%$ & $24 \%$ \\
\hline
\end{tabular}

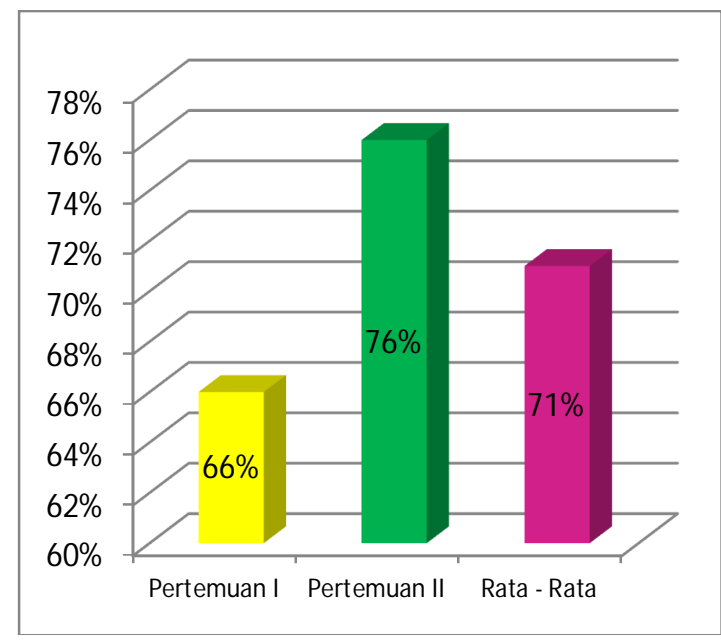

Pada kegiatan pembelajaran dengan dengan model pembelajaran Student Facilitator and Explaininghasil belajar pendidikan jasmani pada materi senam iramaketuntasan siswa dari ranah psikomotor pada siklus I pertemuan I sebanyak $62 \%$ dan pertemuan II $71 \%$. Rata - rata ketuntasan siswa siklus I 67\%. Dari ranah kognitif ketuntasan siswa siklus I pertemuan I 66\% dan siklus I Dari hasil yang peroleh belum pertemuan II ketuntasan siswa sebesar $76 \%$ setelah digabungkan pertemuan I dan II diperoleh ketuntasan siswa ranag kognitif siklus I sebesar $71 \%$. Pada kegiatan pembelajaran yang dilakukan hasil belum memuaskan dan perlu dilakukan reflesi terhadap kelemahan siswa dalam kegiatan pembelajaran.

\section{Aktivitas Guru dan Siswa Siklus I}

Dalam kegiatan pembelajaran aktivitas guru dalam mengajar dan keaktifan siswa dalam belajar dengan model pembelajaran Student Facilitator and Explainingdiamati oleh observer, adapun hasil pengamatan aktivitas guru dan siswa siklus I sebagai berikut:

Tabel 3: Aktivitas Guru dan Siswa

\begin{tabular}{|c|l|c|c|}
\hline \multirow{2}{*}{ Aktivitas } & \multicolumn{2}{|c|}{ Nilai } & \multicolumn{2}{|c|}{$\begin{array}{l}\text { Rata }- \\
\text { Rata }\end{array}$} \\
\hline \multirow{2}{*}{ Aktivitas Guru } & Siklus I P1 & 78 & \multirow{2}{*}{$83 \%$} \\
\cline { 2 - 3 } & Siklus I P2 & 87 & \\
\hline \multirow{2}{*}{ Keaktifan Siswa } & Siklus I P1 & 70 & \multirow{2}{*}{$77 \%$} \\
\cline { 2 - 3 } & Siklus I P2 & 84 & \\
\hline
\end{tabular}

Dari data di atas diperoleh data bahwa aktivitas guru dalam menyajikan 
pelajaran dengan model pembelajaran Student Facilitator and Explaining pada materi senam irama belum sempurna, masih terdapat beberapa aspek atau langkah model pembelajaran Student Facilitator and Explaining yang kurang terlaksana oleh guru dengan baik pada siklus I pertemuan I dalam mengajar dengan rata - rata aktivitas guru dalam melakukan model pembelajaran Student Facilitator and Explaining dalam pembelajaran adalah $78 \%$ terlaksana dengan kriteria baik. Pada siklus I pertemuan II aktivitas guru dalam mengajar dengan model pembelajaran Student Facilitator and Explaining baru terlaksana $87 \%$. Jika dirata- ratakan hasil aktivitas guru mengajar dengan model pembelajaran Student Facilitator and Explaining siklus I yaitu $83 \%$. Jika dilihat dari indikator keberhasilan pada penelitian ini yaitu 85 atau $>85 \%$. Maka pada siklus I ini belum berhasil dan perlu dilanjutkan pada siklus II.

Dalam pengamatan aktivitas siswa dalam pembelajaran pendidikan jasmani dengan model pembelajaran Student Facilitator and Explaining siklus I pertemuan I rata - rata nilai siswa yang sudah aktif dari aspek yang diamati sebanyak $70 \%$ dan siklus I pertemuan II rata - rata siswa yang sudah aktif belajar dengan model pembelajaran Student Facilitator and Explaining sebanyak 84\%. Setelah digabungkan nilai pertemuan I dan II diperoleh aktivitas siswa yang aktif pada siklus I yaitu sebanyak $77 \%$ siswa. jika di lihat indikator keberhasilan pada penelitian ini yaitu $85 \%$ atau lebih dari $85 \%$ maka aktivitas siswa perlu diperbaiki pada siklus II dan dilakukan refleksi lagi.

\section{Siklus II}

\section{Hasil Belajar Siswa}

Setelah dilakukan refleksi terhadap kelemahan pada siklus I hasil belajar pendidikan jasmani pada materi senam irama dengan model pembelajaran Student Facilitator and Explaining, adapun hasil belajar siswa siklus II dari ranah psikomotor dan kognitif sebagai berikut:

Tabel 4:Hasil Belajar Psikomotor Siklus II

\begin{tabular}{|c|c|c|c|}
\hline \multicolumn{2}{|c|}{ Siklus I Pertemuan I } & \multicolumn{2}{c|}{ Siklus I Pertemuan II } \\
\hline $\begin{array}{c}\text { Siswa } \\
\text { Tuntas }\end{array}$ & $\begin{array}{c}\text { Siswa belum } \\
\text { tuntas }\end{array}$ & Siswa tuntas & $\begin{array}{r}\text { Siswa } \\
\text { Belum } \\
\text { Tuntas }\end{array}$ \\
\hline $86 \%$ & $14 \%$ & $90 \%$ & $10 \%$ \\
\hline
\end{tabular}

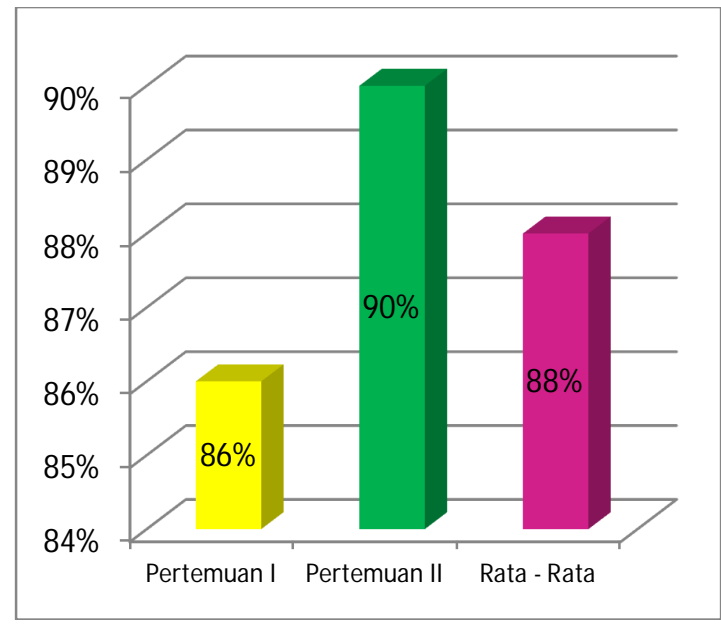

Tabel 5:Hasil Belajar Kognitif Siklus II

\begin{tabular}{|c|c|c|c|}
\hline \multicolumn{2}{|c|}{ Siklus I Pertemuan I } & \multicolumn{2}{c|}{ Siklus I Pertemuan II } \\
\hline $\begin{array}{c}\text { Siswa } \\
\text { Tuntas }\end{array}$ & $\begin{array}{c}\text { Siswa belum } \\
\text { tuntas }\end{array}$ & Siswa tuntas & $\begin{array}{c}\text { Siswa Belum } \\
\text { Tuntas }\end{array}$ \\
\hline $90 \%$ & $10 \%$ & $95 \%$ & $5 \%$ \\
\hline
\end{tabular}

Pada siklus II pertemuan I keseluruhan dari penilaian tulis pad

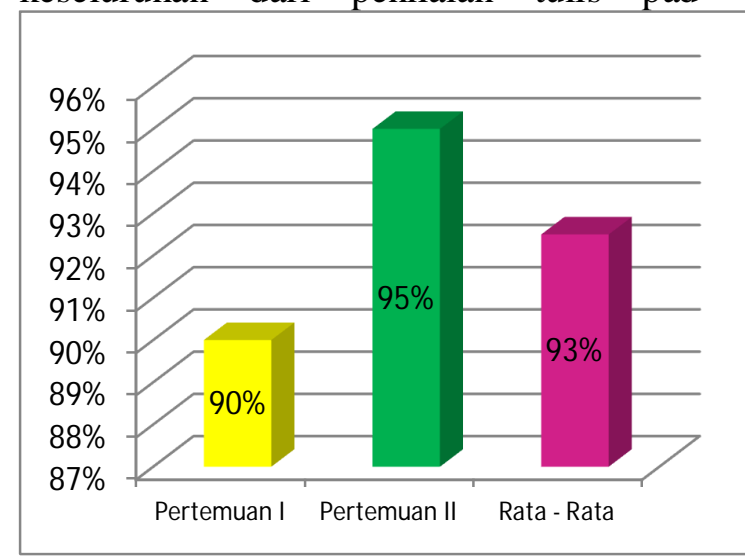

a materi senam irama dalam pembelajaran 
pendidikan jasmani siswa sudah banyak yang melakukan gerak dasar senam irama terbukti ketuntasan siswa sebanyak 18 orang dengan persentase $86 \%$ siswa yang tuntas. Pada siklus II pertemuan II ini sebanyak 19 orang siswa telah tuntas dalam melakukan gerak dasar senam irama dengan persentase $90 \%$. Setelah digabungkan pertemuan I dan II maka diperoleh hasil belajar siklus II yaitu $88 \%$ siswa tuntas dalam pendidikan jasmani dengan model pembelajaran Student Facilitator and Explaining.Jika dilihat dari indikator keberhasilan pada penelitian ini yaitu 85 atau $>85 \%$. Maka pada siklus II ini sudah berhasil.

Pada siklus II pertemuan I keseluruhan dari penilaian tulis pada materi senam irama dalam pembelajaran pendidikan jasamani siswa sudah banyak yang memahami materi terbukti ketuntasan siswa secara kognitif ini sebanyak 19 orang dengan persentase $90 \%$ siswa yang tuntas. Pada siklus II pertemuan II ini siswa yang sudah tuntas sebanyak 20 orang (95\%). Jika diagbungakn maka diperoleh hasil belajar siklus II yaitu $93 \%$ siswa tuntas dalam pembelajaran pendidikan jasamani dengan model pembelajaran Student Facilitator and Explaining. Jika dilihat dari indikator keberhasilan pada penelitian ini yaitu 85 atau $>85 \%$. Maka pada siklus II ini sudah berhasil.

\section{Aktivitas Guru dan siswa}

Setelah dilakukan refleksi pada siklus I terhadap kelemahan guru dalam mengajar dengan model pembelajaran Student Facilitator and Explainingdan keaktifan siswa diperoleh dari hasil pengamatan aktivitas guru dan keaktifan siswa oleh observer, adapun hasil pengamatan aktivitas guru dan keaktifan siswa siklus II sebagai berikut:

Tabel 6: Aktivitas Guru dan Siswa

\begin{tabular}{|c|c|c|c|}
\hline \multirow{2}{*}{ Aktivitas } & \multicolumn{2}{|c|}{ Nilai } & \multicolumn{2}{|c|}{$\begin{array}{l}\text { Rata - } \\
\text { Rata }\end{array}$} \\
\hline \multirow{2}{*}{ Aktivitas Guru } & Siklus II P1 & 93 & \multirow{2}{*}{$94 \%$} \\
\cline { 2 - 3 } & Siklus II P2 & 96 & \\
\hline \multirow{2}{*}{ Keaktifan Siswa } & Siklus II P1 & 93 & \multirow{2}{*}{$95 \%$} \\
\cline { 2 - 3 } & Siklus II P2 & 97 & \\
\hline
\end{tabular}

Dari data di atas diperoleh data bahwa aktivitas guru dalam menyajikan pelajaran dengan model pembelajaran Student Facilitator and Explainingpada materi senam irama sudah sangat baik, sedikit kelemahan guru mengajar dengan langkah model pembelajaran Student Facilitator and Explaining. Pada siklus II pertemuan I rata - rata aktivitas guru dalam melakukan pembelajaran dengan model pembelajaran Student Facilitator and Explaining dalam pembelajaran adalah 93\% terlaksana dengan kriteria sangat baik. Pada siklus II pertemuan II jumlah skor pengamatan aktivitas guru adalah 96\%. Setelah digabungkan pertemuan I dam II di peroleh aktivitas guru siklus II yaitu $94 \% /$ Jika dilihat dari indikator keberhasilan pada penelitian ini yaitu 85 atau $>85 \%$. Maka pada siklus II ini sudah berhasil.

Dalam pengamatan aktivitas siswa dalam pembelajaran pendidikan jasmani dengan model pembelajaran Student Facilitator and Explaining siklus II pertemuan I rata - rata nilai siswa yang sudah banyak siswa yang aktif dari aspek yang diamati sebanyak $93 \%$ dan siklus II pertemuan II rata - rata siswa yang sudah aktif dalam belajar pendidikan jasmani dengan model pembelajaran Student Facilitator and Explainingyaitu sebanyak 97\%. Setelah digabungkan nilai pertemuan I dan II diperoleh persentase siswa yang aktif pada siklus II yaitu sebanyak 95\% siswa. jika di lihat indikator keberhasilan pada penelitian ini yaitu $85 \%$ atau lebih dari $85 \%$ maka aktivitas siswa sudah berhasil pada siklus II ini.

\section{PEMBAHASAN}

\section{Hasil belajar}

Pembahasan hasil penelitian siklus I meliputi: perencanaan peningkatan hasil belajar pada pembelajaran pendidikan jasmani pada materi senam irama dengan model pembelajaran Student Facilitator and Explaining. Pada kegiatan pembelajaran dengan model pembelajaran Student Facilitator and Explaininghasil 
belajar pendidikan jasmanidari ranah psikomotor pada materi senam irama ketuntasan siswa pada siklus I pertemuan I siswa tuntas pada pendidikan jasamni62\% dan siklus I pertemuan II siswa tuntas sebanyak $71 \%$. Setelah digabungkan pertemuan I dan II diperoleh nilai siklus I yaitu $67 \%$. Setelah di refeleksi pada siklus I hasil belajar siswa pembelajaran pendidikan jasmani pada materi senam irama dengan model pembelajaran Student Facilitator and Explainingpada siklus II pertemuan I ketuntasan siswa sebanyak 86\% dan siklus II pertemuan II sebanyak $90 \%$. Setelah digabungkan pertemuan I dan II pada siklus II diperoleh ketuntasan siswa pada siklus II sebanyak $88 \%$. Terjadi peningkatan $21 \%$ dari siklus I ke siklus II ketntasan belajar siswa.

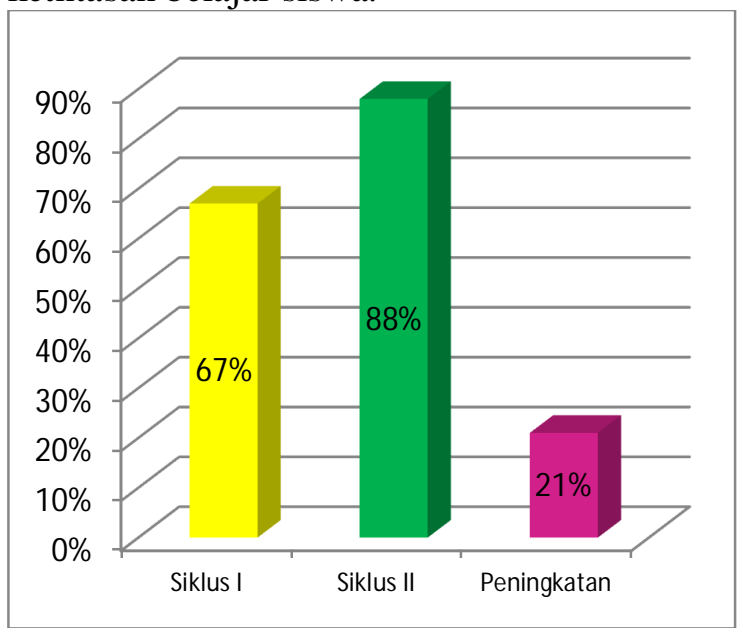

Pada ranah kognitif siklus I pertemuan I ketuntasan siswa $66 \%$ dan siklus I pertemuan II $76 \%$ dan setelah digabungkan pertemuan I dan II ketuntasan siklus I menjadi $71 \%$. Setelah dilakukan refleksi pada siklus I ketuntasan siklus II pertemuan I ketuntasan $90 \%$ dan siklus II pertemuan II ketuntasan siswa 95\% pada ranah kognitif. Setelah digabungkan pertemuan I dan II diperoleh ketuntasan siswa ranah kognitif siklus II menjadi 93\%. Terjadi peningkatan sebesar $22 \%$ dari siklus I ke siklus II pada ranah kognitif. Jika dilihat dari indikator keberhasilan pada penelitian ini yaitu $85 \%$ atau $>85 \%$ maka penelitian ini sudah berhasil karena keuntasan siswa melebihi $85 \%$. Untuk lebih rinci persentase peningkatakan siswa yang tuntas dari siklus I ke siklus II lihat grafik di bawah ini:

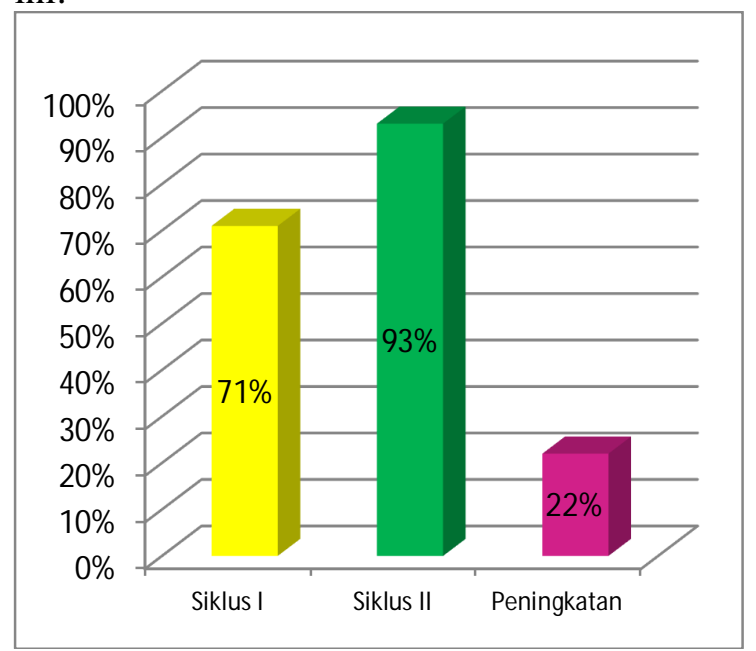

\section{Aktivitas Guru}

Pada siklus I dalam melakukan pembelajaran pendidikan jasmani pada materi senam irama dengan model pembelajaran Student Facilitator and Explainingbelum sesuai harapan dengan rata - rata kemampuan guru mengajar dengan model pembelajaran Student Facilitator and Explainingpada pembelajaran pendidikan jasmani pada materi senam irama dengan model pembelajaran Student Facilitator and Explainingpada siklus I pertemuan I secara keseluruhan dari semua aspek yang dinilai adalah $78 \%$ terlaksana. Pada siklus I pertemuan II hasil pengamatan aktivitas guru yaitu $87 \%$. Setelah digabungkan diperoleh hasil pengamatam aktivitas guru siklus I yaittu $83 \%$. Setelah dilakukan refleksi terhadap kelemahan pada siklus I terjadi peningakatan yang signifikan menjadi aktivitas guru melakukan pembelajaran pembelajaran pendidikan jasmani pada materi senam irama dengan model pembelajaran Student Facilitator and Explainingpada siklus II Pertemuan I menjadi $93 \%$ dan siklus II pertemuan II meneningkat aktivitas guru yaitu 96\% terlaksana. Setelah digabungkan pertemuan I dan II diperoeh nilai aktivitas guru siklus II yaitu 94\% terlaksana. Guru dalam proses pembelajaran mampu mengajar dengan baik dan mampu 
mempengaruhi hasil belajar siswa. Terjadi peningkatan sebesar $11 \%$. Secara keseluruhan pada siklus II ini guru sduah mampu mengajar dengan sangat baik mengajar pendidikan jasmani pada materi senam irama dengan model pembelajaran Student Facilitator and Explaining. Jika dilihat dari indikator keberhasilan pada penelitian ini yaitu $85 \%$ atau $>85 \%$ maka penelitian ini sudah berhasil karena aktivitas guru dalam mengajar dengan model pembelajaran Student Facilitator and Explainingsudah $94 \%$ terlaksana. Untuk lebih jelas lihat tabel peningkatan aktivitas guru pada tebel di bawah ini :

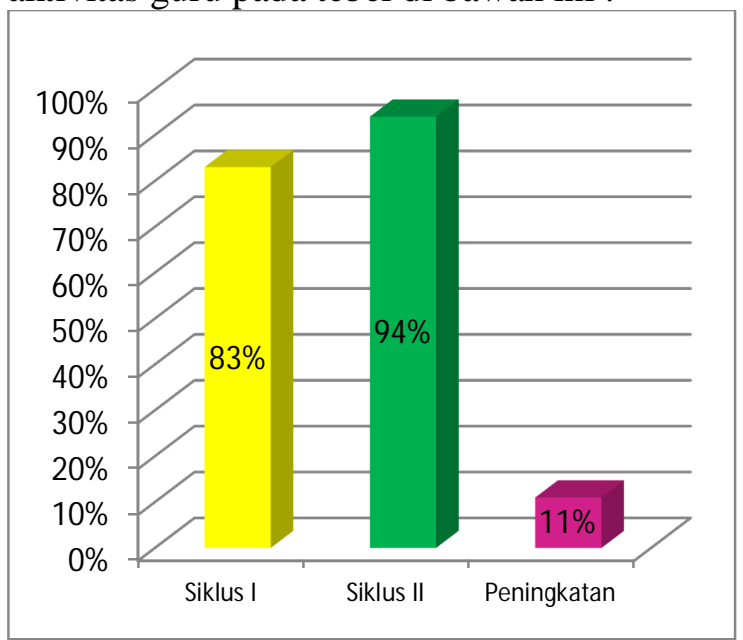

\section{Aktivitas Siswa}

Pada aktivitas siswa dalam kegiatan pembelajaran pendidikan jasmani pada materi senam irama dengan model pembelajaran Student Facilitator and Explaining. Pada siklus I pertemuan I rata - rata keaktifan siswa dalam pembelajaran pendidikan jasmani pada materi senam irama dengan model pembelajaran Student Facilitator and Explaining yaitu 70\%. Pada siklus I pertemuan II rata - rata siswa yang aktif sebanyak $84 \%$. Setelah digabungkan pertemuan I dan II diperoleh keaktifan siswa siklus I yaitu $77 \%$. Setelah di refleksi terhadap kekurangan pada siklus I meningkat aktivitas siswa pada pembelajaran pendidikan jasmani pada materi senam irama dengan model pembelajaran Student Facilitator and Explainingpada siklus II pertemuan I menjadi $93 \%$ dan siklus II pertemuan II meningkat menjadi 97\%. Stelah di gabungkan pertemuan I dan II diperoleh aktivitas siswa siklus II yaitu 95\%. Terjadi peningakatan keaktifan $18 \%$ dari siklus I ke siklus II. Jika dilihat dari indikator keberhasilan pada penelitian ini yaitu $85 \%$ atau $>85 \%$ maka penelitian ini sudah berhasil. Untuk lebih jelas lihat grafik di bawah ini:

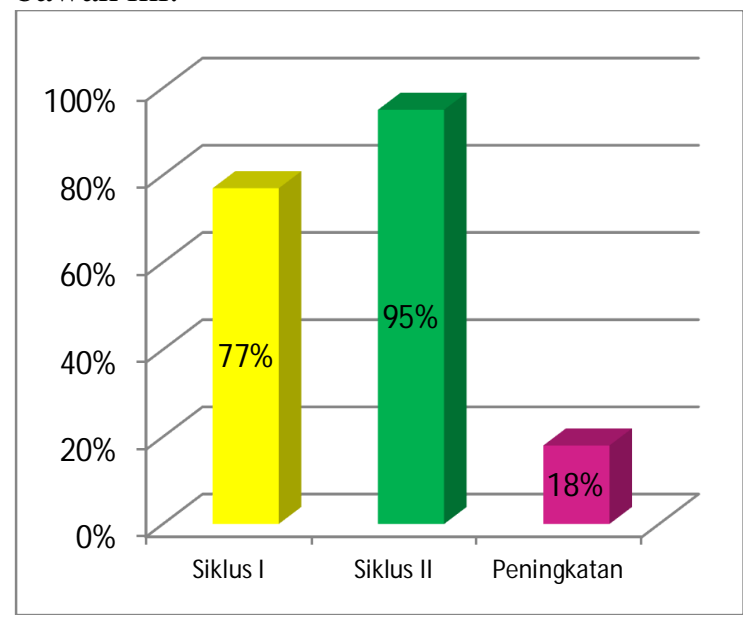

Secara umum penelitian tindakan kelas yang dilakukan untuk meningkatkan hasil belajar pendidikan jasmani pada materi senam irama dengan model pembelajaran Student Facilitator and Explainingdi kelas IV SDN 23 Koto Gadang Hilir Kecamatan Padang Ganting Kabupaten Tanah Datar. Dimana terjadi peningkatan pada seluruh aspek yang di amati dan di nilai. Berdasarkan data diatas maka penelitian tindakan kelas ini sudah berhasil karena suda berada diatas indiktor keberhasilan yang telah ditetapkan yaitu $>85 \%$.

\section{KESIMPULAN DAN SARAN Kesimpulan}

Berdasarkan pembahasan diatas diambil simpulan sebagai berikut:

1. Melalui model pembelajaran Student Facilitator and Explainingdapat meningkatkan hasil belajar pendidikan jasmani pada materi senam irama pada siswa kelas IV SDN 23 Koto Gadang Hilir Kecamatan Padang Ganting Kabupaten Tanah Datar. Hal ini dibuktikan ketuntsan siswa 
ranah psikomotor pada siklus I $67 \%$ setelah di refleksi meningktan pada siklus II menjadi $88 \%$ terjadi peningkatan sebesar $21 \%$ dan ranah kognitif ketuntasan siswa siklus I $71 \%$ dan siklus II $93 \%$ terjadi peningkatan sebesar $22 \%$.

2. Aktivitas guru dalam kegiatan pembelajaran model pembelajaran Student Facilitator and Explaininguntuk meningkatkan hasil belajar pendidikan jasmani pada materi senam irama pada siswa kelas IV SDN 23 Koto Gadang Hilir Kecamatan Padang Ganting Kabupaten Tanah Datar sangat baik dan meningkat, terbukti aktivitas guru siklus I $83 \%$ terlaksana setelah direfleksi meningkat pada siklus II menjadi $94 \%$ terlaksana $11 \%$.

3. Aktivitas siswa dalam kegiatan pembelajaran dengan modelpembelajaran Student Facilitator and Explaining untuk meningkatkan hasil belajar belajar pendidikan jasmani pada materi senam irama pada siswa kelas IV SDN 23 Koto Gadang Hilir Kecamatan Padang Ganting Kabupaten Tanah Datar sangat baik dan meningkat, terbukti aktivitas siswa siklus I $77 \%$ terlaksana setelah direfleksi meningkat pada siklus II menjadi 95\% terlaksana terjadi peningkatan $18 \%$.

\section{Saran}

Berdasarkan hasil penelitian ini dapat disarankan:

1. Dalam setiap pembelajaran, khususnya tentang Pendidikan jasmani perlu adanya metode pembelajaran maupun teknik pembelajaran yang dapat menarik perhatian dan minat siswa serta siswa aktif dalam pembelajaran salah satunya model pembelajaran Student Facilitator and Explaining.
2. Guru dalam mengajar hendaknya mampu meciptakan pembelajaran yang bisa membuat siswa termotivasi sehingga siswa berminat memahami materi dengan sungguh - sungguh dan belajar dengan teman sebaya.

\section{DAFTAR PUSTAKA}

Ade Rusliana. 2007. Konsep Dasar Evaluasi Hasil Belajar. Jakarta. Bumi Aksara

Agus Suprijono. 2009. Cooperative Learning Teori \& Aplikasi Paikem. Yogyakarta: Pustaka Pelajar.

Arikunto.Suharsimi, 2002. Prosedur Penelitian Suatu Pendekatan Praktek. Jakarta: Rineka Cipta

Depdiknas. 2006. Kurikulum Tingkat Satuan Pendidikan Jenjang Pendidikan Dasar. Jakarta: Depdiknas

Kosasih, Engkos. 1992. Olahraga Teknik dan Program Latihan. Jakarta: Akademika Presindo

Hamalik, Oemar. 2008. Kurikulum dan Pembelajaran. Jakarta: Sinar Grafika

Kunandar. 2007. Guru Profesional: Implementasi Kurikulum Tingkat Satuan Pendidikan (KTSP) dan Sukses dalam Sertifikasi Guru. Jakarta: Rajagrafindo Persada

Kunandar.2008.Langkah _ Langkah Penelitian Tindakan Kelas Sebagai Pengembangan Profesi Guru. Jakarta. PT Raja Grafindo Persada.

Nana Sudjana. 2009. Penilaian HasilProses Belajar Mengajar. Bandung:Remaja Rosdakarya. 
Rochiati Wiriaatmadja. 2005. Metode Penelitian Tindakan Kelas. Bandung: PT Remaja Rosdakarya

Suryobroto, Agus. 2004. Sarana dan Prasarana Pendidikan Jasmani: Universitas

Yogyakarta:Fakultas Negeri Keolahragaan

Suherman Wawan S. 2004. Kurikulum Berbasis Kompetensi Pendidikan Jasmani Teori dan Praktik Pengembangan. Yogyakarta: FIKUNY
Sukintaka. 2001.Teori Bermain untuk D2 PGSD Penjasorkeskes. Yogyakrta: Depdikbud Dirjen Dikti

Undang - undang Nomor 20 Tahun 2003 tentang Sistem Pendidikan Nasional 